Lepr Rev (1992) 63, 247-254

\title{
Leprosy control in 7 districts of South Sulawesi, Indonesia, 1986-91
}

\author{
ROSMINI DAY,* P LEVER $† \&$ MUH ASRI $\ddagger$ \\ * Leprosy Control, Directorate General of Communicable Disease \\ Control and Environmental Health, Ministry of Health, Jakarta; \\ $\dagger N S L$ Assistance Project to the Provincial Leprosy Control Pro- \\ gramme of South Sulawesi, Ujung Pandang; $\ddagger$ Communicable \\ Disease Control Section, Provincial Health Services South Sulawesi, \\ Ujung Pandang
}

\section{Accepted for publication 11 March 1992}

\begin{abstract}
Summary This paper describes the leprosy control programme in 7 districts of the South Sulawesi Province in Indonesia. This province is reported to have the highest prevalence of leprosy in the country. The programme started in 1986 with re-registration of all patients on the cumulative registers. Strict criteria for admission of patients to MDT were initially applied. In 1990 it appeared that these criteria had been too strict, thus necessitating a second re-registration of patients still on DDS monotherapy. More flexible criteria for admission to MDT led to an increase in MDT coverage from $45 \%$ to $78 \%$ within 6 months.

By April 1991, 5 years after the start of the programme, the registered prevalence had decreased from 4.4 per 1000 in 1986 to 1.6 per 1000; the coverage with MDT had increased from $6 \%$ in 1986 to $78 \%$, and the case detection rate remained stable around 4 per 10,000 after an initial increase at the start of the programme.
\end{abstract}

\section{The area}

South Sulawesi is one of the 27 provinces of the Republic of Indonesia and is subdivided into 21 districts and municipalities. The total population in 1989 was $6,731,224$, with $44 \%$ of the population under 15 years of age. The area on which this report is based consists of the 7 southern districts of South Sulawesi with a total population of 1,750,112 (Table 1). ${ }^{1}$

The province is mostly mountainous, with some low altitude plateaus in the centre, and a lowland area along the coast, where the majority of the population lives. Most of these coastal people belong to the Buginese or Makassarese tribes, which both have a long tradition of seafaring and trading within and beyond the whole Indonesian archipelago. The provincial capital is Ujung Pandang, Indonesia's fifth largest city, with a population of almost 1 million. The first line of the health services is formed by the Puskesmas or 
Table 1. Size and population of the 7 districts in South Sulawesi

\begin{tabular}{lrc}
\hline District & Size $(\mathrm{km} \mathrm{sq})$ & Population 1989 \\
\hline Gowa & $1,883 \cdot 3$ & 400,272 \\
Takalar & $566 \cdot 5$ & 195,176 \\
Jeneponto & $737 \cdot 6$ & 263,997 \\
Bantaeng & $395 \cdot 8$ & 140,037 \\
Bulukumba & $1,154 \cdot 7$ & 333,371 \\
Sinjai & $819 \cdot 5$ & 184,777 \\
Maros & $1,619 \cdot 1$ & 232,482 \\
& & \\
Total & $7,176 \cdot 6$ & $1,750,112$ \\
\hline
\end{tabular}

Community Health Centre, usually staffed with at least 1 doctor and several paramedical and administrative staff. At present there are 254 Puskesmas in South Sulawesi. Leprosy control is integrated into the general health services, and controlled from the Puskesmas. Technical supervision and guidance is provided by specialized staff from the provincial and district levels. Referral is possible to the district hospitals, or to the specialized leprosy hospital in Ujung Pandang.

\section{The leprosy problem}

Random sample surveys conducted in collaboration with the $\mathrm{WHO}^{2}$ between 1975 and 1979 indicated an estimated leprosy prevalence ranging from $4 \cdot 2( \pm 3 \cdot 5)$ to $15 \cdot 3( \pm 2 \cdot 4)$ (95\% confidence limits) per 1000 inhabitants in the province. ${ }^{3}$ This high estimated prevalence, combined with the fact that a considerable proportion of the population, including leprosy patients, travelled all over the Indonesian archipelago, thus spreading the infection to other provinces, made leprosy a public health priority in South Sulawesi. Although from 1982 onwards some MDT had been used in several districts, it was not until 1986 that a systematic approach to leprosy control was adopted using WHOrecommended treatment regimens. ${ }^{2}$ Because of the expected size of the problem it was decided to start the programme in the southern part of the province in 7 districts (Gowa, Maros, Takalar, Jeneponto, Bantaeng, Bulukumba and Sinjai), and after the programme had been established apply the same system in the north of the province.

We describe the difficulties encountered, and the results achieved in the leprosy control programme in these 7 districts since its start in 1986.

\section{The situation at the start of the programme and the re-registration}

Before 1986 most leprosy-related activities consisted of random sample prevalence surveys, and the training of paramedical workers, both carried out by the National Leprosy Training Centre (NLTC) in Ujung Pandang. Leprosy control mainly consisted of providing DDS to leprosy patients or community leaders in their vicinity for further distribution. 
Table 2. Registered leprosy patients, MDT coverage and new patients 1986-91

\begin{tabular}{|c|c|c|c|c|c|c|c|c|c|}
\hline \multirow[b]{2}{*}{1 April } & \multicolumn{3}{|c|}{ On register } & \multirow{2}{*}{$\begin{array}{c}\text { Prevalence } \\
1,000\end{array}$} & \multirow{2}{*}{$\begin{array}{l}\text { MDT } \\
(\%)\end{array}$} & \multicolumn{3}{|c|}{ New patients } & \multirow{2}{*}{$\begin{array}{c}\text { CDR per } \\
10,000\end{array}$} \\
\hline & MB & PB & Total & & & MB & PB & Total & \\
\hline 1986 & 2,613 & 4,967 & 7,580 & $4 \cdot 4$ & 6 & 124 & 322 & 446 & $2 \cdot 6$ \\
\hline 1987 & 2,289 & 3,570 & 5,859 & $3 \cdot 4$ & 13 & 221 & 444 & 665 & $3 \cdot 9$ \\
\hline 1988 & 2,318 & 3,260 & 5,578 & $3 \cdot 2$ & 18 & 315 & 422 & 737 & $4 \cdot 3$ \\
\hline 1989 & 2,714 & 2,726 & 5,440 & $3 \cdot 1$ & 32 & 368 & 394 & 762 & $4 \cdot 4$ \\
\hline 1990 & 2,620 & 1,561 & 4,181 & $2 \cdot 4$ & 45 & 366 & 303 & 669 & $3 \cdot 8$ \\
\hline 1991 & 2,107 & 807 & 2,914 & $1 \cdot 6$ & 78 & 406 & 315 & 721 & $4 \cdot 0$ \\
\hline
\end{tabular}

Cumulative registers, which went back for 15 years or more, were kept in the Community Health Centres. In the beginning of 1986, there were more than 7500 patients on these registers (prevalence 4.4/1,000) (Table 2 and Figure 1).

Before the planned MDT implementation programme could be embarked upon, clearing the cumulative registers was a priority.

Paramedical workers from the health centres, in collaboration with the district and provincial supervisors collected information on all registered patients from the Health Centre, community leaders, and any other possible source.

Wherever possible patients were then visited at home to determine whether they still needed treatment, or could be removed from the registers.

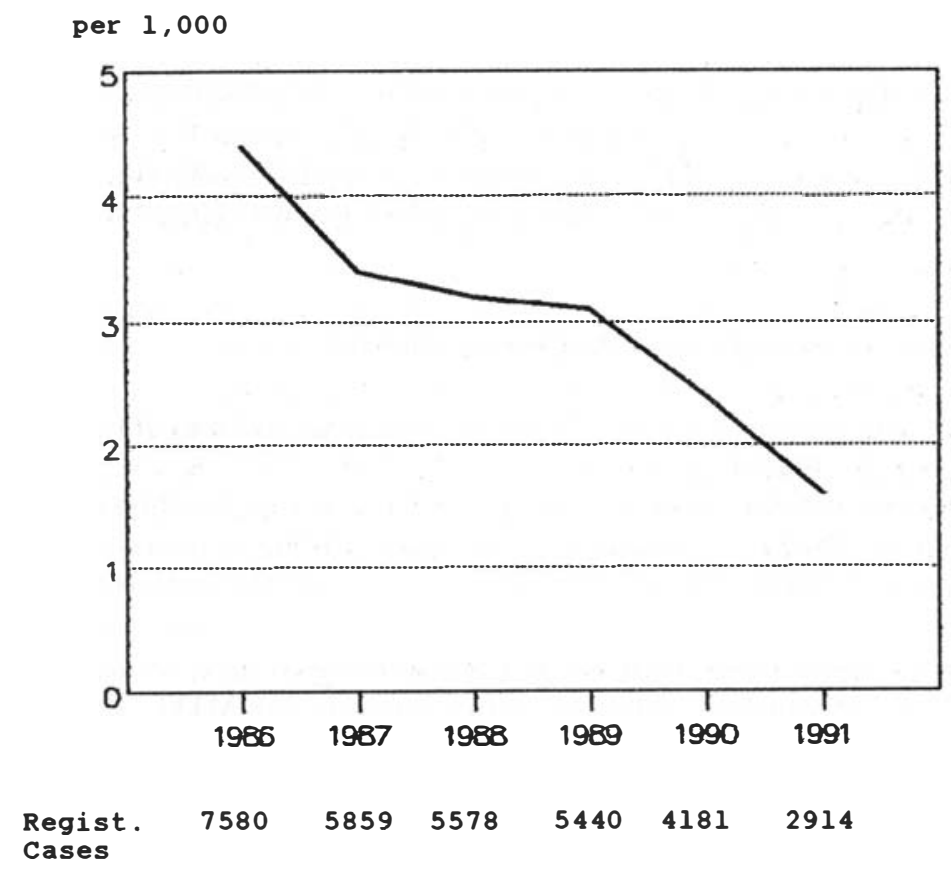

Figure 1. Registered prevalence rate per 1,000. 7 Districts of South Sulawesi, 1986-91. 
Table 3. Results of re-registration

\begin{tabular}{lrr}
\hline & & $\%$ \\
\hline RFC $^{*}$ & 1,009 & 13 \\
Died & 1,319 & 17 \\
Moved & 441 & 6 \\
OOC $\dagger$ & 1,138 & 15 \\
Other deductions $\ddagger$ & 176 & 2 \\
Still in need of treatment & 3,497 & 46 \\
& & \\
Total & 7,580 & \\
\hline
\end{tabular}

* RFC, released from control, $†$ OOC, out of control, $\ddagger$ other deductions includes wrong diagnosis and double registrations.

It appeared that more than 4000 patients could be struck off the registers for reasons shown in Table 3.

Criteria used to determine whether patients still needed treatment were as follows:

PB patients: all patients with active disease, and all patients who had been treated with DDS monotherapy for a period of less than $3 \frac{1}{2}$ years were considered to be in need of treatment.

MB patients: all patients with active disease, all patients with positive skin smears at the time of the re-registration, and all patients who had been treated with DDS monotherapy for a period of less than 10 years were considered to be in need of treatment.

The patients who still needed treatment were started on the WHO recommended MDT, but only if they fulfilled strict conditions for admission to this treatment. These conditions made it essential that patients should come to the Health Centre once per month in order to receive the supervised dose of MDT. If a patient still needed treatment, but was not able to come to the clinic once per month, DDS monotherapy was continued.

\section{The situation after the re-registration had been completed}

The re-registration operation proved very time consuming, and was only fully completed in all 7 districts by the beginning of 1989 .

However, it soon became clear that the health workers in the Puskesmas, and their supervisors from the district, focused their attention almost exclusively on the patients who were treated with MDT. The patients who did not fulfil the criteria for admission to MDT and had been left on DDS monotherapy were not expected to attend the monthly clinics, and DDS was of ten provided for several months at a time, as had been common practice before re-registration. Whereas many patients on MDT, due to the short duration of treatment (especially for PB patients), could soon be discharged from treatment, this was not the case for patients who had remained on DDS monotherapy.

As a result, during 1989, it was noticed that despite the fact that by then almost all new patients were started on MDT, the coverage with MDT, calculated as a point prevalence at the end of the year, did not increase much further. Some districts even started to show a 
slight decline, when the number of MDT patients released from treatment became larger than the number of new patients started on MDT. The denominator in the equation,

$$
\text { MDT coverage }=\frac{\text { Patients on MDT }}{\text { Patients on MDT }+ \text { patients on DDS monotherapy }}
$$

scarcely decreased, due to the large unchanging number of patients on DDS monotherapy.

If a higher MDT coverage was to be achieved, the treatment of the patients who were left on DDS monotherapy during the re-registration had to be re-assessed.

Much more flexible criteria for the admission to MDT were used this time: from now on disabled or elderly patients were to send a relative or neighbour to collect drugs, and where this was impossible blister-calendar packs were used for periods of unsupervised MDT of up to 3 months. By doing this it proved to be possible to increase the coverage of MDT dramatically from $45 \%$ as at 30 September 1990 to $78 \%$ just 6 months later, and further it should be noted, the regularity of treatment did not decrease, but remained around $90 \%$ (Table 2 and Figure 2.)

\section{Discussion}

When the programme started in 1986, it was not the continuation of a well-established DDS monotherapy programme, where merely the treatment schedule had to be changed.

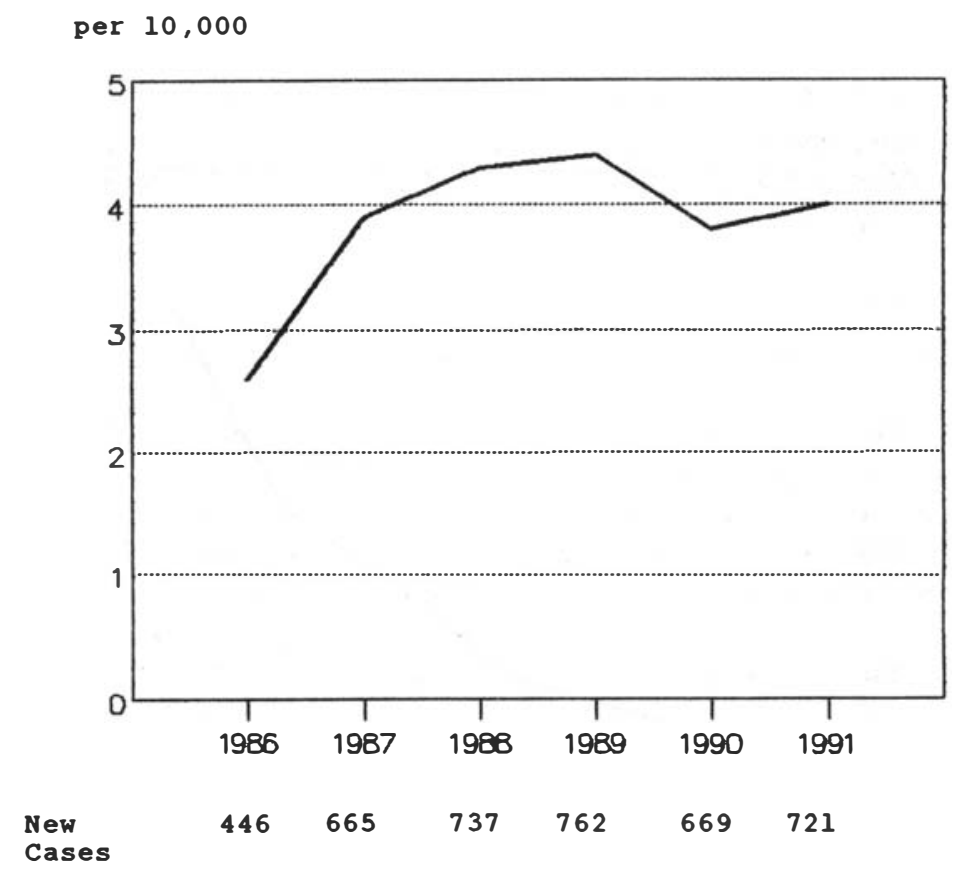

Figure 2. Case detection rate per 10,000. 7 Districts of South Sulawesi, 1986-91. 
In fact it was necessary to build up a whole new programme, which may be best illustrated by the fact that more than 4000 patients could be struck off the registers during the reregistration.

It is well documented that the screening of patients before MDT is introduced in a programme leads to a reduction in patient load because many patients can usually be released from control. ${ }^{4,5}$ However, in the case of South Sulawesi only $25 \%$ of the patients who were removed from the registers were released from control, and the others had already died or simply disappeared.

A welcome 'side-effect' of the operation was that during the re-registration a total of 1457 new patients were encountered. Some of them were household contacts of known patients, others came forward spontaneously, or were reported by fellow villagers.

In 1986, WHO-recommended MDT was still a relatively new treatment scheme, which is why strict criteria for eligibility for MDT treatment were rigidly adhered to. When patients could not come to the Puskesmas once per month they were not started on MDT, thus excluding many elderly and disabled patients, and patients living far away from the clinic. Later it became clear these criteria had been too strict. Re-assessment of patients not yet on MDT was started in 1990, with the aim of providing MDT to all patients still needing treatment. This re-assessment is far less time consuming than the original reregistration, and relatively few patients are being removed from the registers.

A relative disadvantage of changing the treatment scheme from DDS monotherapy to MDT is that a number of disabled patients who had been on DDS monotherapy for a long time, and had expected to continue this treatment for the rest of their lives, are discharged from treatment either during re-registration or after a period of 2 years of MDT. When

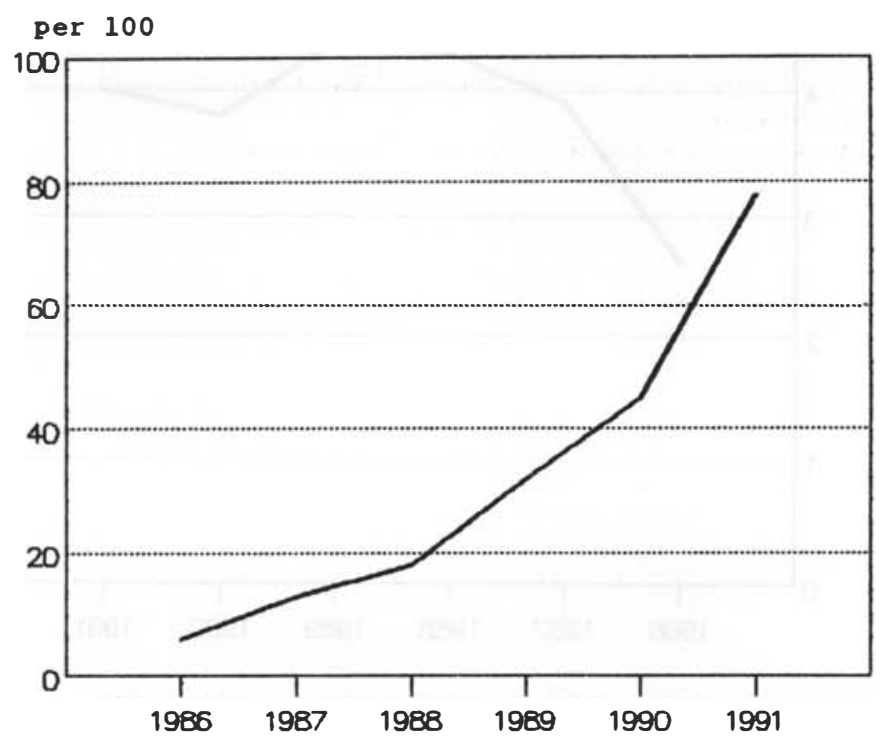

Figure 3. Implementation of MDT. Proportion of registered patients on MDT. 7 Districts of South Sulawesi, 1986-91. 
either active surveillance or a 'care af ter cure' programme do not exist, these patients are at risk of losing whatever little contact with the health service they still had.

The first 5 years of the programme have seen a considerable decline in registered prevalence from $4 \cdot 4 / 1,000$ in 1986 , to $1 \cdot 6 / 1,000$ in 1991 (Table 2 and Figure 1). The sharp decline in the first year is mainly caused by the re-registration activities, the decline from 1989 onwards can be attributed to the shortening of the duration of MDT treatment as is described for many MDT programmes. ${ }^{6-8}$ The case detection rate shows an increase at the start of the programme in 1986, which should be attributed to the increased activities when the MDT programme started (backlog effect). After this initial increase, the case detection rate remains at the same level, and does not yet show a downward trend (Table 2 and Figure 3).

\section{Acknowledgments}

We would like to thank Dr P Feenstra and Dr H Eggens for their helpful and stimulating comments.

\section{References}

1 Statistical Office of Sulawesi Selatan. Propinsi dalam angka (1989) p. 35.

2 WHO Technical Report Series No. 768. Sixth report of the WHO Expert Committee on Leprosy, 1988.

3 Zuiderhoek B, Joewono O, Lechat MF, Misson CB, Declerq E. Prevalence survey of leprosy in South Sulawesi (1979, unpublished report).

4 Jesudasan K, Vijakumaran P, Pannikar VK, Christian M. Impact of MDT on leprosy as measured by seiective indicators. Lepr Rev, 1988; 59: 215-23.

5 Sivaramakrishna Rao, Sirmban P. Screening of registered leprosy cases and its effects on prevalence rate. Ind $J$ Lepr, 1990; 62: 180-5.

6 Behre D, Haimanot RT, Tedla T, Taddesse T. Epidemiological pattern of leprosy in Ethiopia: a review of the control programmes. Lepr Rev, 1990; 61: 258-66.

7 Rose P. Changes in epidemiological indices following WHO MDT into the Guyana leprosy control programme. Lepr Rev, 1989; 60: 151-156.

8 Steenbergen GJ. Leprosy control in Zambia. WH Stat, 1991; 44: 30-35. 


\title{
Contrôle de la Lèpre dans sept districts de la province de south Sulawesi, Indonésie, 1986-1991
}

\author{
R Day, P Lever et M Asri
}

Résumé Cette communication décrit le programme de contrôle de la lèpre dans 7 districts de la Province de South Sulawesi en Indonésie. Cette province est connue comme celle où la fréquence de la lèpre est la plus haute de tout le pays. Le programme a débuté en 1986 avec la ré-inscription de tous les patients sur des registres cumulatifs. Des critères stricts étaient appliqués initialement pour l'admission des patients au MDT. En 1990, il est apparu que ces critères étaient trop stricts, ce qui a nécessité une seconde inscription des patients encore traités par la monothérapie DDS. Des critères plus flexibles pour l'admission à MDT ont abouti à une augmentation de la couverture par MDT de $45 \%$ à $78 \%$ en 6 mois.

Dès Avril 1991, 5 ans après le début du programme, la fréquence recensée avait diminué de 4,4 pour 1000 en 1986 à 1,6 pour 1000; la couverture par MDT avait augmenté de 6\% en 1986 à $78 \%$, et le taux de détection de cas nouveaux était resté stable autour de 4 pour 10,000 après une augmentation initiale au début du programme.

\section{El control de la lepra en 7 distritos de Sulawesi del sur, Indonesia, 1986-1991}

\author{
R DAY, P LEVER y M ASRI
}

Resumen Este artículo describe el programa de control de la lepra en 7 distritos de la Provincia de Sulawesi del Sur en Indonesia. Se ha informado que esta provincia tiene el nivel más elevado del país. El programa comenzó en 1986 con la re-registración de todos los pacientes en registros cumulativos. Al comienzo, se aplicaron criterios estrictos antes de usar TMD. En 1990, se consideró que los criterios eran demasiados estrictos, haciendo necesario una segunda re-registración de los pacientes que continuaban con monoterapia DDS. Criterios más flexibles de admisión al TMD resultó en un aumento de aplicación de TMD, de $45 \%$ a $78 \%$, en un período de 6 meses.

En abril 1991, 5 años después del comienzo del programa, la frecuencia de registración había ba jado de 4,4 por mil en 1986 a 1,6 por mil; el alcance con TMD había aumentado de $6 \%$ en 1986 a $78 \%$, y el nivel de detección de casos permaneció estable en un $4 \%$ por 10,000 después de un aumento inicial al comienzo del programa. 